\title{
Interspecific interactions regulate plant reproductive allometry in cereal-legume intercropping systems
}

Gaudio, Noémie; Violle, Cyrille; Gendre, Xavier; Fort, Florian; Mahmoud, Rémi; Pelzer, Elise; Médiène, Safia; Hauggaard-Nielsen, Henrik; Bedoussac, Laurent; Bonnet, Catherine; Corre-Hellou, Guénaëlle; Couëdel, Antoine; Hinsinger, Philippe; Jensen, Erik Steen; Journet, Etienne-Pascal; Justes, Eric; Kammoun, Bochra; Litrico, Isabelle; Moutier, Nathalie; Naudin, Christophe; Casadebaig, Pierre

Published in:

Journal of Applied Ecology

DOI:

10.1111/1365-2664.13979

Publication date:

2021

Document Version

Early version, also known as pre-print

Citation for published version (APA):

Gaudio, N., Violle, C., Gendre, X., Fort, F., Mahmoud, R., Pelzer, E., Médiène, S., Hauggaard-Nielsen, H., Bedoussac, L., Bonnet, C., Corre-Hellou, G., Couëdel, A., Hinsinger, P., Jensen, E. S., Journet, E-P., Justes, E., Kammoun, B., Litrico, I., Moutier, N., ... Casadebaig, P. (2021). Interspecific interactions regulate plant reproductive allometry in cereal-legume intercropping systems. Journal of Applied Ecology, 58(11), 2579-2589. https://doi.org/10.1111/1365-2664.13979

General rights

Copyright and moral rights for the publications made accessible in the public portal are retained by the authors and/or other copyright owners and it is a condition of accessing publications that users recognise and abide by the legal requirements associated with these rights.

- Users may download and print one copy of any publication from the public portal for the purpose of private study or research. - You may not further distribute the material or use it for any profit-making activity or commercial gain.

- You may freely distribute the URL identifying the publication in the public portal.

Take down policy

If you believe that this document breaches copyright please contact rucforsk@kb.dk providing details, and we will remove access to the work immediately and investigate your claim. 


\section{Interspecific interactions regulate plant reproductive allometry in cereal-legume intercropping}

2 systems

3 Noémie Gaudio ${ }^{1 *}$, Cyrille Violle ${ }^{2}$, Xavier Gendre ${ }^{3}$, Florian Fort ${ }^{4}$, Rémi Mahmoud ${ }^{1}$, Elise Pelzer ${ }^{5}$, Safia

4 Médiène $^{5}$, Henrik Hauggaard-Nielsen ${ }^{6}$, Laurent Bedoussac ${ }^{7}$, Catherine Bonnet ${ }^{1}$, Guénaëlle Corre-Hellou ${ }^{8}$,

5 Antoine Couëdel ${ }^{1}$, Philippe Hinsinger ${ }^{9}$, Erik Steen Jensen ${ }^{10}$, Etienne-Pascal Journet ${ }^{1}$, Eric Justes ${ }^{1,11}$, Bochra

6 Kammoun $^{1}$, Isabelle Litrico ${ }^{12}$, Nathalie Moutier ${ }^{13}$, Christophe Naudin $^{8}$, Pierre Casadebaig ${ }^{1}$

7 correspondence author: noemie.gaudio@inrae.fr

81 University of Toulouse, INRAE, UMR AGIR, Castanet-Tolosan, France

92 UMR 5175 CEFE, Université de Montpellier, CNRS, EPHE, IRD, Université Paul Valéry, Montpellier, France

103 ISAE-SUPAERO, University of Toulouse, 10 Avenue Édouard Belin, 31055 Toulouse, France

114 UMR 5175 CEFE, Univ Montpellier, CNRS, EPHE, Institut Agro, IRD, Université Paul Valery Montpellier, Montpellier, 12 France

135 University Paris-Saclay, AgroParisTech, INRAE, UMR Agronomie, 78850, Thiverval-Grignon, France

146 Department of People and Technology, Roskilde University, DK-4000 Roskilde, Denmark 7 University of Toulouse,

15 INRAE, ENSFEA, UMR AGIR, F-31326, Castanet-Tolosan, France

168 USC ESA-INRAE 1432 LEVA, Ecole Supérieure d'Agricultures, 55 rue Rabelais, BP 30748, 49007 Angers Cedex 01, France

179 Eco\&Sols, Univ Montpellier, INRAE, CIRAD, Institut Agro, IRD, Montpellier, France

1810 Cropping Systems Ecology, Department of Biosystems and Technology, Box 103, SE-230 53 Alnarp, Sweden

1911 CIRAD, Persyst Department, F-34398 Montpellier, France

2012 INRAE, URP3F, Le Chêne - RD 150, BP 6, F-86600 Lusignan, France

2113 INRAE, Agrocampus Ouest, Université de Rennes, IGEPP, F-35650 Le Rheu, France 
24 1. Calling for ecological principles in agriculture has gained momentum. Intercropping systems have long been designed with the objective of optimizing resource use efficiency by growing two, or more, annual crop species in the same field. However, optimization criteria for their design are lacking. Notably, it is still unknown whether and how species performances are maximized during both the vegetative and reproductive phases given the sensitivity of reproductive allocation rules to resource limitation. Interestingly, ecological theory provides expectations regarding putative invariance of plant reproductive allometry (PRA) under non-limiting conditions for plant growth. Here we examined whether and how PRA changes in response to plant-plant interactions in intercropping systems, which represents a major inquiry for both ecological theory and the understanding of the functioning of intercropping systems.

2. We built and analyzed a unique dataset of 28 field cereal-legume intercropping trials from various climatic and management conditions across Western Europe. PRA were quantified in both mixing and single-species situations.

3. Management conditions significantly influenced PRA of the different components of the cropping systems. Deviations to PRA expectations were greater for legumes when grown in mixture, which explains their success in mixtures. The response for cereals was similar in direction but less pronounced in magnitude, and was more significant under limiting resource conditions.

4. Synthesis and applications. PRA matters in crop species in the same way as it does in wild species, suggesting the existence of universal biophysical constraints that cannot be broken by artificial selection. However, contrary to theoretical expectations about an overall invariance of PRA, our meta-analysis highlighted taxon-specific and context-dependent effects of plant-plant interactions on PRA. A systematic exploration of deviation to PRA expectations appears as a relevant tool to assist the management of intercropping systems through the choice of species and genotypes to use and the type of agricultural practices to apply. In turn, such a dialog between agronomy and ecology is a unique opportunity to challenge the validity domain and robustness of major ecological laws.

\section{Keywords}


Intercropping, i.e. combining at least two annual crop species in the same field for most part of their growing periods (Willey, 1979), is a promising way to move towards more sustainable agriculture (Li-li et al., 2015; Lin, 2011). Intercropped species are expected to use resources differently and more efficiently (e.g. Malézieux et al., 2009; Beillouin, Ben-Ari, \& Makowski, 2019; Jensen, Carlsson, \& Hauggaard-Nielsen, 2020). Many intercrops mix a cereal and a legume, with the underlying assumption that the cereal will benefit from the legume's atmospheric nitrogen $(\mathrm{N})$ fixation, thus decreasing the need for exogenous $\mathrm{N}$ fertilization (Gaba et al., 2018; Malézieux, 2012; Thorsted, Weiner, \& Olesen, 2006). The performance of intercropping systems has been studied from an agronomic perspective, focusing mainly on yield and $\mathrm{N}$ use (e.g. Bedoussac \& Justes, 2010b; Hauggaard-Nielsen, Gooding, Ambus, Corre-Hellou, Crozat, Dahlmann, Dahlmann, et al., 2009; Naudin, Corre-Hellou, Pineau, Crozat, \& Jeuffroy, 2010; Pelzer et al., 2012). While introducing species diversity into cropping systems could appear promising under low-input conditions, specific recommendations for the management of intercrops is in its infancy (Litrico \& Violle, 2015). One reason for this is that the underlying mechanisms of the positive effect of the intercropping remain elusive, which makes it challenging to choose species and cultivars for these systems accurately. One key unsolved issue for identifying these mechanisms is how vegetative biomass translates into reproductive biomass and how reproductive allocation differs between sole cropping and intercropping situations. Bridging ecology and agronomy could help resolve this issue.

In ecology, the plant allometry literature has extensively analyzed the change in many key plant features as a function of size. Notably, a large body of theory indicates that plant reproductive output (grain yield for annual cropping systems) is a function of plant size (Weiner, Campbell, Pino, \& Echarte, 2009). It is based on metabolic optimization criteria, in which regulation processes and selection forces have similar influence on size-related traits across taxa (Enquist, West, Charnov, \& Brown, 1999). It forms the basis of metabolic scaling theory (MST), which provides first principles of plant allometry laws (West, Brown, \& Enquist, 1997, 1999). As a macroecological law, MST explains trait variation across several orders of magnitude of taxa, scales and body size. This body of theory attracts interest for the design and management of intercropping systems given the predictive power of universal scaling equations of MST (Deng et al., 2012). 
The hypothesis of invariance at the origin of allometric scaling laws has been challenged. Poorter et al. (2015)

highlighted that allometric scaling exponents differ among species. Vasseur, Violle, Enquist, Granier, \& Vile (2012) and Vasseur et al. (2018) highlighted variability in these exponents within the model species Arabidopsis thaliana, and demonstrated that this variability was genetically determined and environmentally regulated due to natural selection. Further, the influence of artificial selection on allometric constraints is not well understood due to the lack of comparisons of allometric relationships in crop species (Milla, Osborne, Turcotte, \& Violle, 2015). The initial MST framework was designed along with plant observations in optimal conditions, i.e. where growth is not strongly limited by unfavorable abiotic or biotic conditions. Consequently, the influence of plant-plant interactions and soil resource limitations on deviations from MST expectations remains unknown (but see Coomes, Lines, \& Allen, 2011; Vasseur et al., 2018). Intercropping systems represent a unique opportunity to challenge allometric laws, in order to fine-tune them and assess the validity of their most basic assumptions. Understanding the influence of plant-plant interactions on reproductive strategies of intercropped species would improve the understanding, modeling and ultimately management of intercrops (Gaudio et al., 2019), particularly to drive each species to its potential reproductive output in relation to the other species and the cropping conditions. In this study, we analyzed how plant allometry is related to the performance of intercropped species and how this relationship is influenced by varying cropping conditions. Crop scientists and stakeholders, including farmers, are primarily interested in yield, often assessed in intercropping systems by the land equivalent ratio in order to calculate land-use efficiency (e.g. Yu, Stomph, Makowski, Zhang, \& Werf, 2016). Finer analysis of intercrop performance would improve our understanding of the mechanisms underlying intercrop performance.

We examined the influence of plant-plant interactions on the allometric relationship between grain yield production and plant biomass in annual cereal-legume intercrops grown under a variety of climatic and cropping conditions in Western Europe, with the underlying objective to test the MST under non-optimal conditions, characterized here by the plant-plant interactions and soil nutrient limitations. Our analysis was based on 28 field experiments. The main objective of this study was to investigate how the reproductive allometric relationships of both plant families (cereals and legumes) changed depending on whether they were grown in a sole crop or with another crop. We also focused on the influence of $\mathrm{N}$ fertilization within each plant family and crop type (sole crop vs. intercrop). The strength of allometric relationships can indicate 
that the ratio of yield to plant size does not vary, as the relationship between these two variables is supposed to be invariant (Nee, Colegrave, West, \& Grafen, 2005). This ratio is called "reproductive effort" in ecology (Cheplick, 2005) and "harvest index" in agronomy (Echarte \& Andrade, 2003; Vega, Sadras, Andrade, \& Uhart, 2000). It is often used to focus on allocation of biomass to reproductive organs and to differentiate performances of species and cultivars (Hay, 1995), which is a framework that is complementary to MST. Thus, we also assessed the influence of crop management on reproductive efforts of the two plant families.

\section{Materials and methods}

\section{Field experiments}

We collected a set of experiments that compared different species and cultivars under intercropping and sole-cropping conditions under a variety of management practices in 9 locations in five European countries (France, Denmark, Italy, Germany, and the United Kingdom) (Fig. 1). The experiments covered 28 environments (location $\mathrm{x}$ year), of which 15 were managed as organic farming and 13 as conventional farming, with a total of 34 intercropping situations (environment $x$ species) and 62 sole-cropping situations. Since the experiments were not completely factorial, i.e. not all factors (cultivars, $\mathrm{N}$ fertilization, sowing density) were combined, we analyzed a total of 159 and 219 experimental units under intercropping and sole-cropping situations, respectively. In the experiments, $53 \%$ and $47 \%$ of the intercropped species were winter and spring crops, respectively. The mean temperature over the crop cycle (from sowing to harvest) ranged from $6.8-11.3^{\circ} \mathrm{C}$ for winter crops and $12.3-15.1^{\circ} \mathrm{C}$ for spring crops. Cumulative rainfall ranged from 278-713 mm for winter crops and 60-366 $\mathrm{mm}$ for spring crops.

Additional details on experimental designs and management practices are reported in Supplementary Material S1 and in the reference publications for 22 of the 28 experiments (Bedoussac \& Justes, 2010a, 2010b; Corre-Hellou, Fustec, \& Crozat, 2006; Hauggaard-Nielsen, Gooding, Ambus, Corre-Hellou, Crozat, Dahlmann, Dahlmann, et al., 2009a; Hauggaard-Nielsen, Gooding, Ambus, Corre-Hellou, Crozat, Dahlmann, Dibet, et al., 2009b; Hauggaard-Nielsen, Jørnsgaard, Kinane, \& Jensen, 2008; Knudsen, Hauggaard-Nielsen, Jornsgard, \& Jensen, 2004; Launay et al., 2009; Naudin et al., 2010; Naudin, Werf, Jeuffroy, \& Corre-Hellou, 2014; Pelzer, Bazot, Guichard, \& Jeuffroy, 2016; Tang et al., 2016). 
A)

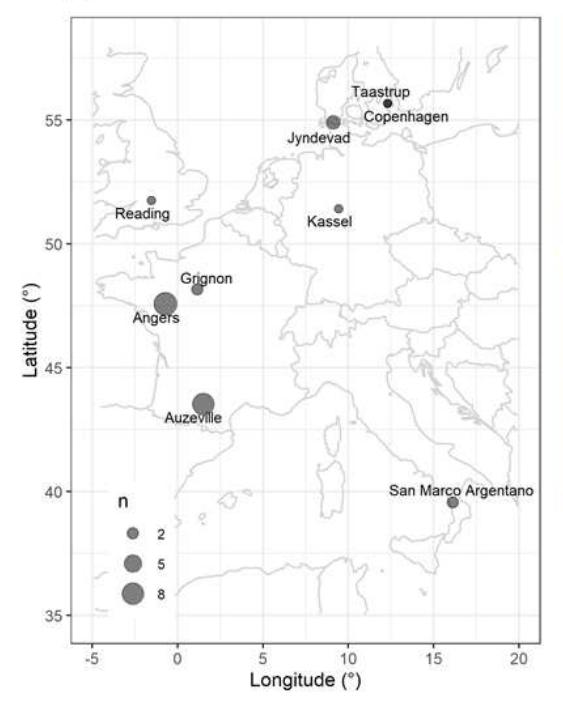

B)

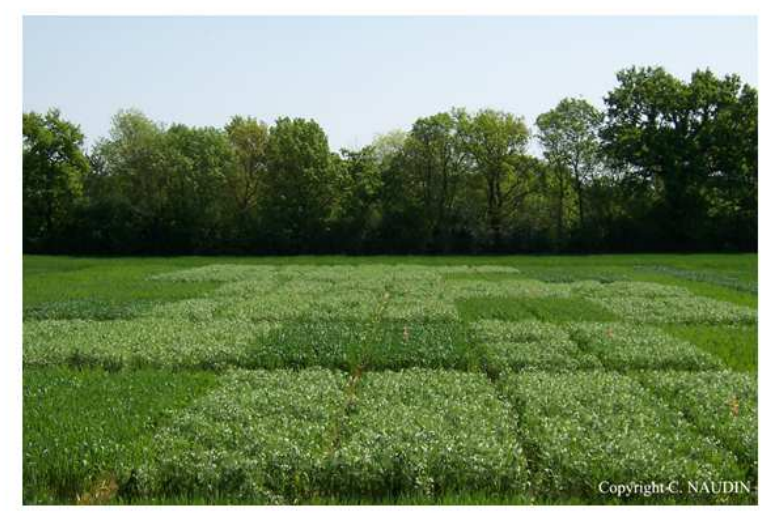

Fig. 1. (A) Number of field experiments (size of the circle) conducted at each location and (B) example of a field experiment of winter wheat-pea intercrops (and their corresponding sole crops) conducted at the ARVALIS experimental station, near Angers, France (Source: C. Naudin).

The set of experiments included annual cereal-grain legume intercrops and their corresponding sole crops, with i) barley (Hordeum vulgare L.), durum wheat (Triticum turgidum L.) and soft wheat (Triticum aestivum L.) as the cereals (only Poaceae), and ii) faba bean (Vicia faba L.) and pea (Pisum sativum L.) as the legumes (Fabaceae). The cross between crop species and cropping seasons resulted in five intercropping combinations: two spring intercrops (barley-faba bean and barley-pea) and three winter intercrops (durum wheat-faba bean, durum wheat-pea and soft wheat-pea). In all experiments, the two intercropped species were sown and harvested at the same time, with sowing dates ranging from March 11 to May 03 for spring crops and October 25 to December 15 for winter crops.

Within a given cropping situation, variations were related mainly to i) the number of cultivars tested per crop species (ranging from 1-5); ii) the relative sowing density of each species (actual:reference sowing density ratio, 1.0 and 0.5 for sole crops and $0.3-0.7$ for each of the two intercropped species) and iii) the $\mathrm{N}$ fertilization, with non-fertilized and N-fertilized situations, the latter ranging from 30-200 kg N.ha-1 (mean $( \pm$

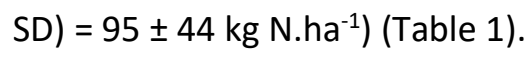

To assess reproductive effort and allometry, all experiments measured at least three variables: grain yield (t.ha- $\left.{ }^{-1}\right)$, total aboveground biomass (t.ha ${ }^{-1}$, including grains, flowers, pods and ears) at maturity, and actual 
plant density (plant. $\mathrm{m}^{-2}$ ). Plant density was used to convert per-ha variables into per-capita variables (i.e. g. plant $^{-1} ;$ Table 1).

Table 1. Cropping situations pooled in the database by plant family (Poaceae vs. Fabaceae), crop type (sole crop vs.

153 intercrop) and nitrogen (N) fertilization (non-fertilized NO vs. N-fertilized). Several cultivars and crop species densities

154 (relative proportions) were represented for each factor combination (family $\mathrm{x}$ crop type $\mathrm{x} \mathrm{N}$ fertilization). Mean $( \pm \mathrm{SD}$ ) total plant aboveground dry biomass and grain yield were calculated for each factor combination.

\begin{tabular}{|c|c|c|c|c|c|c|c|}
\hline Plant family & Crop type & $\mathrm{N}$ fertilization & No. cropping situations & No. cultivars & No. densities & Biomass (g.plant ${ }^{-1}$ ) & Yield (g.plant ${ }^{-1}$ ) \\
\hline \multirow{4}{*}{$\begin{array}{l}\text { Cereal } \\
\text { (Poaceae) }\end{array}$} & \multirow[t]{2}{*}{ Sole crop } & NO & 57 & 12 & 2 & $3.8 \pm 1.8$ & $1.5 \pm 0.6$ \\
\hline & & $\mathrm{N}$ & 57 & 11 & 2 & $6.8 \pm 3.0$ & $2.7 \pm 1.1$ \\
\hline & \multirow[t]{2}{*}{ Intercrop } & NO & 103 & 12 & 5 & $3.5 \pm 1.7$ & $1.5 \pm 0.8$ \\
\hline & & $\mathrm{N}$ & 56 & 9 & 6 & $6.8 \pm 2.1$ & $2.8 \pm 0.9$ \\
\hline \multirow{4}{*}{$\begin{array}{l}\text { Legume } \\
\text { (Fabaceae) }\end{array}$} & \multirow[t]{2}{*}{ Sole crop } & No & 87 & 18 & 2 & $20.9 \pm 16.7$ & $9.0 \pm 5.9$ \\
\hline & & $\mathrm{N}$ & 18 & 8 & 2 & $35.3 \pm 25.5$ & $16.0 \pm 12.5$ \\
\hline & \multirow[t]{2}{*}{ Intercrop } & No & 103 & 18 & 5 & $15.2 \pm 11.4$ & $7.8 \pm 5.8$ \\
\hline & & $\mathrm{N}$ & 56 & 8 & 6 & $16.0 \pm 12.5$ & $7.4 \pm 5.7$ \\
\hline
\end{tabular}

\section{Data processing and analysis}

158 Reproductive effort was calculated as the ratio of grain yield to total aboveground biomass at maturity, rather 159 than final biomass, to avoid the influence of leaves that dropped before maturity (Unkovich, Baldock, \& 160 Forbes, 2010). Analysis of variance (ANOVA) was performed using the aov function of the stats package of $R$ 161 software (R Core Team, 2019). When relevant $(p<0.05)$, means were separated using a Tukey or, when 162 ANOVA assumptions were not met, Kruskal-Wallis test. We performed one-way ANOVAs within each plant 163 family (Poaceae vs. Fabaceae) to test the influence of crop type (sole crop vs. intercrop) and $\mathrm{N}$ fertilization 164 (non-fertilized vs. N-fertilized) on reproductive effort and its components (i.e. plant aboveground biomass and plant yield). The influence of $\mathrm{N}$ fertilization could not be assessed for legumes in sole crops due to 
unequal sample sizes (18 situations fertilized, 87 non-fertilized) (Table 1). For the same reason, differences between sole crops and intercrops for legumes could be assessed only under non-fertilized conditions.

168

We analyzed reproductive allometric relationships between plant grain yield and plant aboveground biomass thanks to standardized major axis analysis (SMA; Warton, Wright, Falster, \& Westoby, 2006; Poorter \& Sack, 2012) using the R smatr package (Warton, Duursma, Falster, \& Taskinen, 2012), through the power relation $y=a x^{b}$, where $y$ and $x$ are plant yield and aboveground biomass, respectively. This method enables geometrical interpretations that lead to statistical testing procedures to compare slope, offset and shift along the allometric line (Taskinen \& Warton, 2013; Warton et al., 2012). More specifically, we assessed the effect of plant family and, within each family, the effect of crop type and $\mathrm{N}$ fertilization, on the position of individual plants along the main reproductive allometric line. Because of the unequal sample sizes, allometric lines for legumes were compared only i) under non-fertilized conditions, to compare the effect of crop type, and ii) in intercrops, to compare the effect of $\mathrm{N}$ fertilization.

When two groups had significantly different slopes of allometric lines, we determined the aboveground biomass for which the two allometric lines intersect, thus defining the plant-size threshold above which a plant had a proportionally higher yield. For example, this threshold equaled the abscissa $X_{0}$ of the intersection of the allometric relationships for an intercrop (IC) and sole crop (SC), calculated as $X_{0}=\frac{a_{I C}-a_{S C}}{b_{S C}-b_{I C}}$, where $a_{I C}$ and $a_{s c}$ are the estimated intercept, and $b_{I c}$ and $b_{s c}$ are the least square estimate of the slope of the allometric relationship for an intercrop and sole crop, respectively. We calculated $95 \%$ confidence intervals (CI0.95) of this threshold using the procedure of Filliben \& McKinney (1972).

To assess the dominance of the focal species in intercrop, we calculated a distance index based on biomass difference (i.e. fitness distance, Mayfield \& Levine, 2010; Cadotte, 2017) between the two intercropped species within each of the 159 experimental units in intercropping situations. We first normalized plant yield and biomass values within species $\mathrm{x}$ fertilization groups to account for major plant size differences between intercropped species (unity-based normalization, $x^{\prime}=\frac{x-x_{\max }}{x_{\max -x_{\min }}}$ ). Then, considering an intercrop mixing two species $i$ and $j$, the biomass distance index for the focal species $i$ was defined as $x_{j-}^{\prime} x_{i}^{\prime}$, and respectively for 
species $j$. This index ranges from -1 (i.e. focal species is dominant) to +1 (i.e. focal species is dominated). We used a linear model to analyze change in plant yield as a function of the biomass distance index.

The allometric relationships led to centered residuals as the differences between the observed yield and the predicted one from associated biomass. A natural question arose about the impact of the conditions of each experiment on these results. Considering an ANOVA or a mixed model would be unsatisfying due to the unbalanced sizes of each experimental group in the dataset. Thus, an alternative approach was proposed to tackle such a question. The residual values were plotted separately for each subset of data obtained in the same conditions. Moreover, the $p$-th quantiles for $p=2.5 \%$ and $p=97.5 \%$ were drawn to bounds $95 \%$ of residual values to visualize possible outliers (Supplementary Material S2). The results indicated that no extreme value appeared as remarkable. Some variability is revealed but its order of magnitude remains below the dispersal of the residuals. The role of the experimental factors appears then as neglectable with respect to the residual variations of the allometric relationships.

Data were analyzed with R software version 3.6.0 with the packages dplyr (data processing; Wickham, François, Henry, \& Müller, 2019), ggplot2 (visualization; Wickham, 2016) and knitr (reporting; Xie, 2015).

\section{Results}

\section{Reproductive allometry in cereals and legumes}

The reproductive allometric relationship between plant yield and biomass was significant and robust $\left(R^{2}=0.94\right)$ across all experimental units, indicating that size is a predominant driver of crop yield. Allometric relationships of legumes and cereals displayed a similar slope close to $1(1.03 \pm 0.02)$, indicating an overall isometric relationship between plant yield and biomass. However, legumes generally had larger biomass and grain yield than cereals (significant shift along the main relationship, Fig. 2A). Moreover, legumes generally had higher yield than cereals for a given biomass (significant offset along the $y$-axis). The relationships between reproductive effort and plant biomass were weak for both cereals and legumes $\left(R^{2}=0.104\right.$ and 0.049, respectively), with reproductive effort decreasing slightly as plant biomass increased $(p<0.0001$, 
Fig. 2B). Legumes had slightly but significantly higher reproductive effort $(0.48 \pm 0.10$, ranging from 0.19 $0.73)$ than cereals $(0.43 \pm 0.08$, ranging from $0.22-0.67)$, although it varied greatly.

A

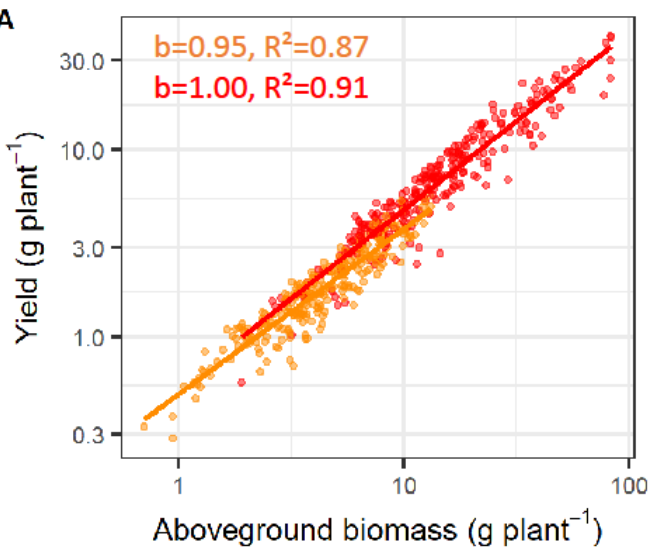

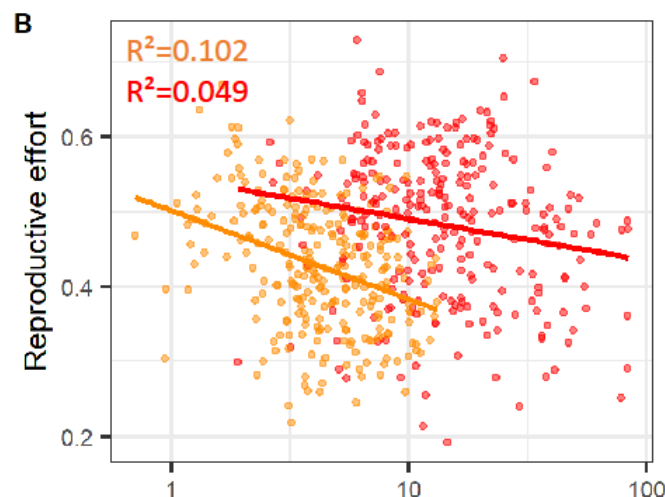

Aboveground biomass (g plant ${ }^{-1}$ )

Fig. 2. (A) Reproductive allometric relationship (log-log scale) between plant yield (g.plant ${ }^{-1}$ ) and plant biomass (g.plant ${ }^{-1}$ ) and (B) relationship between reproductive effort (=yield:biomass) and plant biomass (g.plant ${ }^{-1}$ ) for cereals (orange) and legumes (red) for all experimental units in intercropping and sole-cropping situations.

\section{Crop management impacted the plant reproductive allometry, especially for legumes}

The slopes of allometric relationships were steeper under intercropping than sole-cropping conditions (Fig. 3A-C). The intercropping effect was stronger in non-fertilized conditions (legumes, $p<10^{-6}$; then cereals $p=0.004$ ) than in fertilized conditions (cereals, $p=0.03$ ). For legumes under non-fertilized conditions, intercrops had significantly higher reproductive effort than sole crops. Although allometric differences were observed for cereals, ANOVAs indicated that intercropping had no significant effect on reproductive effort or its components (plant yield and biomass) whether in fertilized or non-fertilized conditions (Table 2).

We calculated the plant size threshold corresponding to the intersection of allometric lines in intercrop and sole crop conditions to identify the minimum plant size corresponding to a positive intercropping effect on biomass allocation (increased yield for a same plant size). The plant size threshold above which a legume under non-fertilized conditions (Fig. 3A) benefited from intercropping was 10.3 g.plant ${ }^{-1}(\mathrm{Cl0} .95=[6.7-13.5$ g.plant $\left.{ }^{-1}\right]$ ), with biomass ranging from 1.9-83.2 g.plant ${ }^{-1}$. For a cereal under non-fertilized conditions (Fig. 3B), the threshold was 3.5 g.plant ${ }^{-1}\left(\mathrm{Cl} 0.95=\left[2.0-5.9\right.\right.$ g.plant $\left.\left.{ }^{-1}\right]\right)$, with biomass ranging from 0.7-9.9 g.plant ${ }^{-1}$. For a cereal under $\mathrm{N}$-fertilized conditions (Fig. 3C), the threshold was 6.3 g.plant ${ }^{-1}$, with biomass ranging from 

two datasets had high collinearity and widely scattered points.
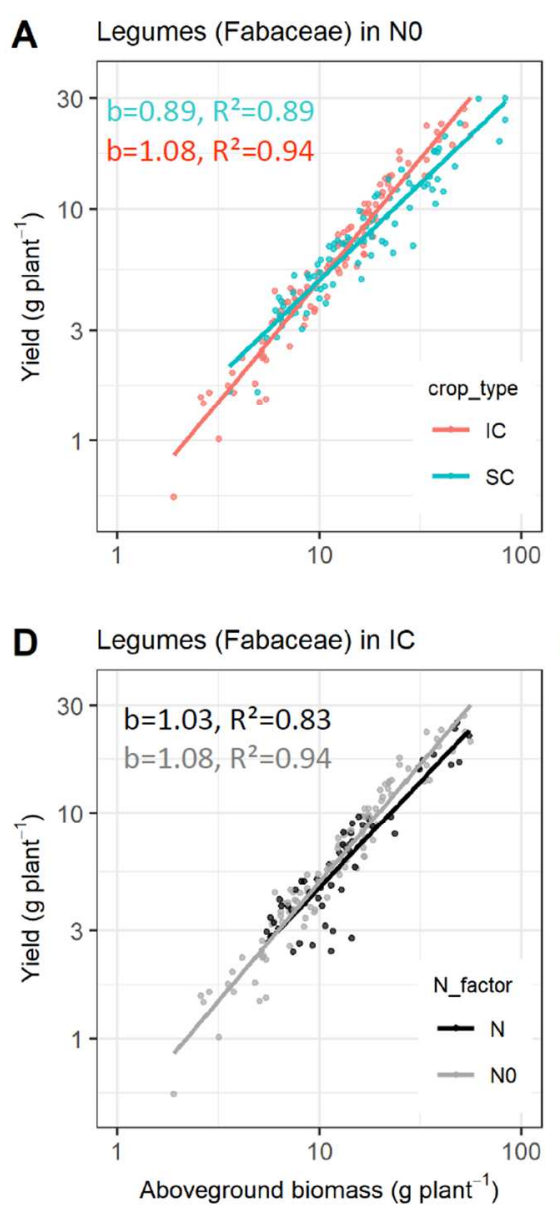

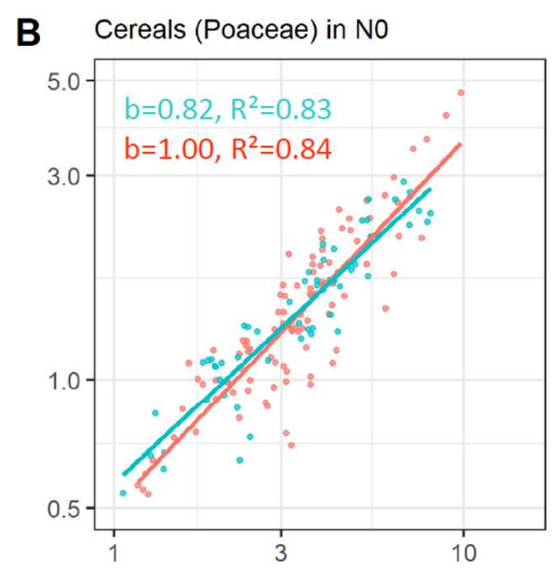

C Cereals (Poaceae) in $\mathrm{N}$

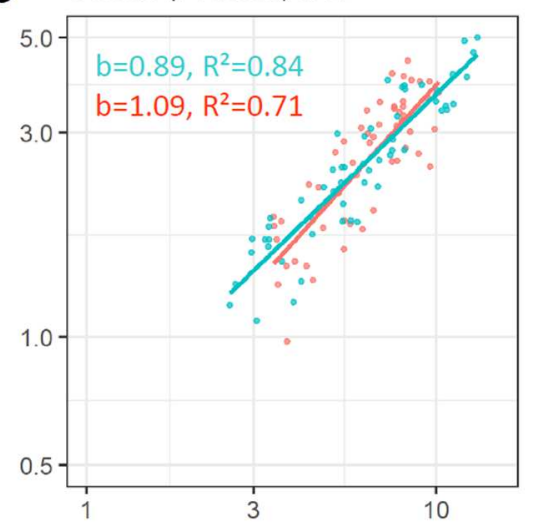

E Cereals (Poaceae) in SC

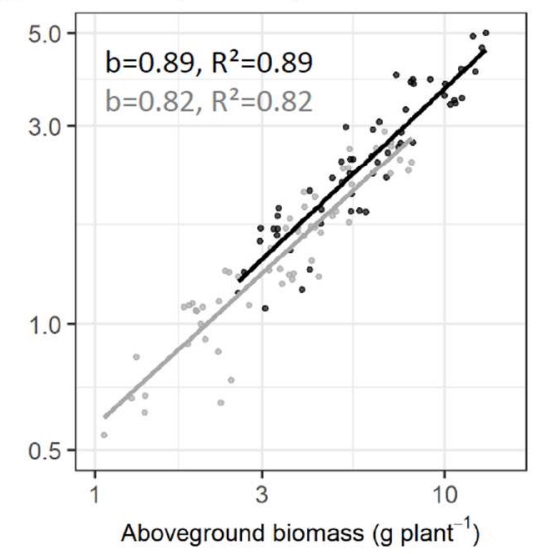

F Cereals (Poaceae) in IC

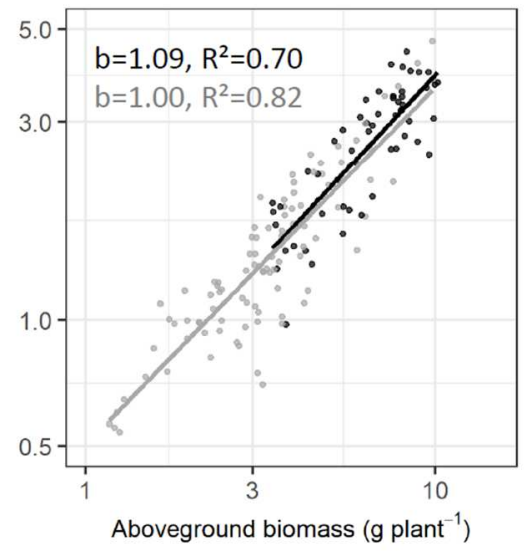

Fig. 3. Reproductive allometric relationship (log-log scale) between plant yield (g.plant ${ }^{-1}$ ) and plant biomass (g.plant ${ }^{\boxplus 1}$ ) by i) crop type (i.e. sole crop (SC) vs. intercrop (IC)), for (A) legumes (Fabaceae) under non-fertilized conditions (NO), (B) cereals (Poaceae) under NO and (C) cereals under N-fertilized conditions (N), and by ii) N fertilization, for (D) legumes grown under IC, (E) cereals under SC and (F) cereals under IC. b represents the allometric scaling exponent of the studied relationships. distance between the two intercropped species. This distance index strongly explained yield variation (Fig. 4), with a decreasing slope (lesser sensitivity to the other species) from non-fertilized legumes $(a=-0.52$, $r 2=0.68)$, non-fertilized cereals $(a=-0.45, r 2=0.65)$, and fertilized cereals $(a=-0.39, r 2=0.47)$. 
A Legumes (Fabaceae) in NO

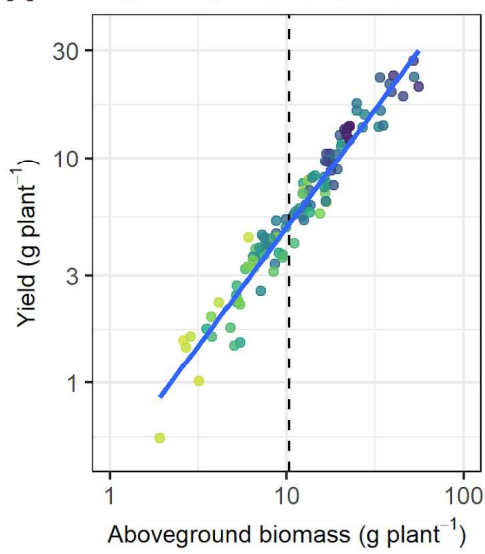

B Cereals (Poaceae) in NO

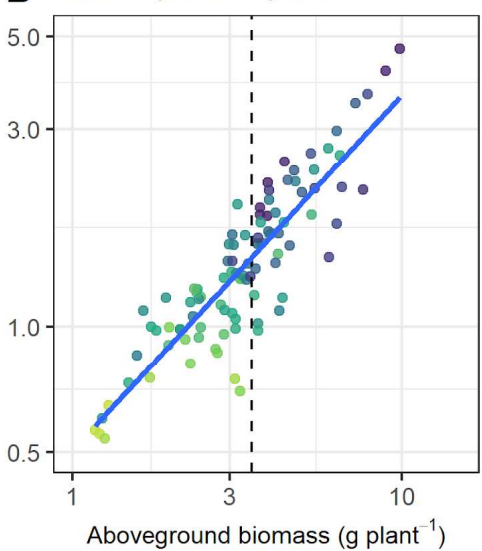

C Cereals (Poaceae) in $\mathrm{N}$

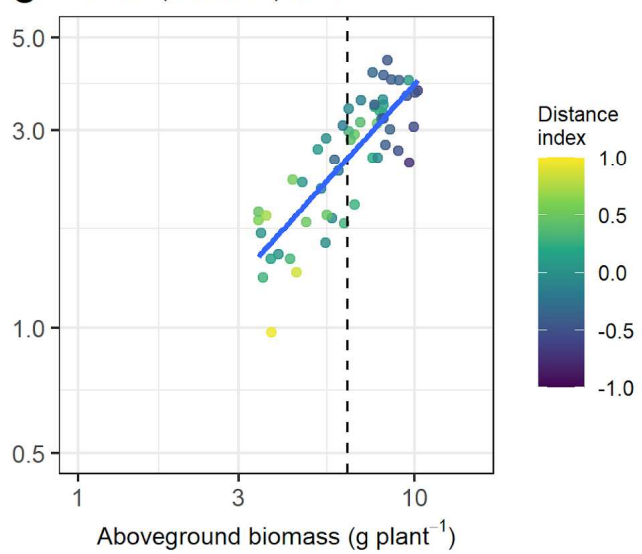

Fig. 4. Reproductive allometric relationship (log-log scale) between plant yield (g.plant ${ }^{-1}$ ) and plant biomass (g.plant $\left.{ }^{-1}\right)$ in intercrops, for (A) legumes (Fabaceae) under non-fertilized conditions (NO), (B) cereals (Poaceae) under N0 and (C) cereals under $\mathrm{N}$-fertilized conditions (N). The biomass distance between the focal species and its associated species is encoded by the color gradient. Vertical dotted lines correspond to the intersection of allometric lines between sole crops and intercrops in Fig. 3.

$\mathrm{N}$ fertilization also influenced allometric relationships (Fig 3D-F). For a given plant biomass, intercropped legumes had higher yield without $\mathrm{N}$ fertilization than with it (significant offset, Fig. 3D). The analysis of the reproductive effort confirmed this result, with significantly higher biomass allocation for legumes under nonfertilized $(0.51 \pm 0.09)$ than $\mathrm{N}$-fertilized $(0.47 \pm 0.11)$ conditions. However, we could not determine whether biomass or yield caused this difference. For cereals, $\mathrm{N}$ fertilization did not influence the allometric relationship: $\mathrm{N}$-fertilized plants had proportionally larger biomass and yield, regardless of the crop type (significant shift, Fig. 3E-F). This result was confirmed by both crop types having a similar reproductive effort: both ratio components (plant biomass and yield) were higher under $\mathrm{N}$-fertilized conditions than nonfertilized conditions, regardless of the crop type.

Table 2. Effect of crop type (sole crop SC vs. intercrop IC) and nitrogen (N) fertilization (non-fertilized NO vs. fertilized N) by plant family (Poaceae vs. Fabaceae) on i) reproductive effort, plant biomass (g.plant ${ }^{-1}$ ) and plant yield (g.plant ${ }^{\boxplus 1}$ ) using analysis of variance and ii) allometric relationships (slope, offset and shift along the relationship) using standardized major axis (SMA) analysis $\left(* * *<0.0001, * *<0.001,{ }^{*}<0.05\right.$, ns non-significant). 


\begin{tabular}{|c|c|c|c|c|c|c|c|c|}
\hline \multirow[b]{2}{*}{ Plant family } & \multirow[b]{2}{*}{ Factor } & \multirow[b]{2}{*}{ Condition } & \multicolumn{3}{|c|}{ Analysis of variance } & \multicolumn{3}{|c|}{ SMA analysis } \\
\hline & & & Reproductive effort & Biomass & Yield & Slope & Offset & Shift \\
\hline \multirow{4}{*}{$\begin{array}{l}\text { Cereal } \\
\text { (Poaceae) }\end{array}$} & \multirow{2}{*}{ Crop type } & Non-fertilized & ns & ns & ns & $*$ & - & - \\
\hline & & $\mathrm{N}$-fertilized & ns & ns & ns & $*$ & - & - \\
\hline & \multirow{2}{*}{$\mathrm{N}$ fertilization } & Sole crop & ns & $* * *(\mathrm{~N} 0<\mathrm{N})$ & $* * *(\mathrm{NO}<\mathrm{N})$ & ns & ns & $* * *$ \\
\hline & & Intercrop & ns & $* * *(\mathrm{~N} 0<\mathrm{N})$ & $* * *(\mathrm{~N} O<\mathrm{N})$ & ns & ns & $* * *$ \\
\hline \multirow{2}{*}{$\begin{array}{l}\text { Legume } \\
\text { (Fabaceae) }\end{array}$} & Crop type & Non-fertilized & $*(\mathrm{SC}<\mathrm{IC})$ & $* *(S C>I C)$ & ns & $* * *$ & - & - \\
\hline & $\mathrm{N}$ fertilization & Intercrop & $*(\mathrm{NO}>\mathrm{N})$ & ns & ns & ns & $*$ & ns \\
\hline
\end{tabular}

\section{Discussion}

271 Intercrop design aims to improve resource-use efficiency, especially crop $\mathrm{N}$ use (yield per unit of $\mathrm{N}$ absorbed)

272 in cereal-legume intercrops (Jensen et al., 2020). In the experiments examined, plant-plant interactions in

273 intercropping conditions influenced reproductive allometry. These results increase knowledge about the

274 factors that influence plant allometry while the allometric rules are usually considered invariant across

275 species and ecological situations, notably as expected from the metabolic scaling theory (MST; Niklas \&

276 Enquist, 2001). Moreover MST appears as a new and promising conceptual framework to improve intercrop

277 management. The allometric approach improves our understanding of which intercropping situation favors

278 one species or the other, and provides some guidelines to identify putative trade-offs depending on the

279 agronomic objective assigned to the intercrop (e.g. focus on the legume, or having both intercropped species

280 reaching a suitable yield without one species strongly dominating the other).

281 In addition to the strong size-dependence of grain yield production, which was predicted by allometric 282 relationships and highlighted in other studies (Liu, Wang, Wei, \& Wang, 2008; Qin, Weiner, Qi, Xiong, \& Li, 283 2013; Sugiyama \& Bazzaz, 1998; Vega et al., 2000; Weiner, 2004), we observed that species grown in 284 intercrops had a greater increase in yield for a given increase in plant size than species grown in sole crops 285 through the threshold analysis (x-coordinate of the intersection of allometric lines between sole cropping 286 and intercropping conditions). This highlights a better spatial and temporal resource use efficiency in a field 287 situation, which is a pillar of ecological intensification (Li-li et al., 2015).

288 This effect depends on plant family and the relative dominance of the two intercropped species. When 289 ranking this effect among cropping conditions, intercropping benefited legumes under non-fertilized 290 conditions the most, followed by cereals under non-fertilized conditions and then cereals under $\mathrm{N}$-fertilized 
conditions. For example, a cereal plant in a sole crop is surrounded by other cereal plants. Since cereal plants generally compete strongly for soil resources, they experience strong intra-specific competition under nonfertilized conditions. If this cereal plant is intercropped with legume plants, however, some of its close neighbors are legumes, which compete less for soil N than cereals (Mariotti, Masoni, Ercoli, \& Arduini, 2009; Satorre \& Snaydon, 1992) and can fix atmospheric N. This decreases the competition experienced by the cereal plant due to functional complementarity in N acquisition strategy (Duchene, Vian, \& Celette, 2017; Hinsinger et al., 2011). However, when the intercrop is fertilized with $\mathrm{N}$, cereals have a competitive advantage over legumes and complementarity for resource use is replaced with strong interspecific competition from the cereal over the legume. Thus, intercrop design should focus on three key points: i) plant family, characterized by their competitive ability (Goldberg, 1990); ii) characteristics of the two intercropped species, to consider the plant neighborhood (Gaudio et al., 2019; Stoll \& Weiner, 2000); and iii) abiotic resource availability.

The relaxation of competitive interaction in intercropping situations is highlighted by the strong effect of biomass differences between the two intercropped species on grain yield production (also called fitness distance in the ecological literature; Cadotte 2017). This reflects the difference in dominance between the two intercropped species (Mayfield \& Levine, 2010), which is one key driver for competitive exclusion. Then, in intercrops, yield of cereals in $\mathrm{N}$-fertilized conditions is hardly influenced by the biomass of the legume, whereas cereals in non-fertilized and then legumes in non-fertilized were much more influenced. When the biomass difference between the two intercropped species is high, there is an obvious imbalance between the two species, leading to strong differences in competitive ability of the two components of the mixture:

311 the greater the biomass difference, the more intense hierarchical competition (Kunstler et al., 2016). 312 Therefore, around the size threshold corresponding to the intersection between allometric lines in sole- and 313 intercropping conditions identified for each cropping situation, the two intercropped species do not reach 314 their maximal size and associated yield but an equilibrium exists between them. When we move away from 315 this threshold, one intercrop component becomes highly dominant or conversely dominated due to hierarchical competition. 
For legumes, we showed that fertilization decreases the reproductive effort (i.e. lower yield for a given

biomass) compared to that under non-fertilized intercropping situations, as highlighted in other studies (e.g.

Corre-Hellou, Brisson, Launay, Fustec, \& Crozat, 2007 for spring barley-pea). This is probably because when strong competition limits a resource, plants tend to allocate more biomass to structures associated with acquiring it, potentially to the detriment of reproductive organs (Bonser, 2013; Poorter \& Nagel, 2000). In contrast, cereals in intercrops had similar reproductive effort whatever the fertilization condition, but a given reproductive effort was reached with proportionally higher biomass and yield in fertilized plots. In these cropping conditions, cereals are larger and compete more for aboveground and soil resources. Understanding the causal processes for such a modified allocation would require targeted experiments that measure key functional traits of legumes that reflect plant behavior for light (e.g. specific leaf area) and $\mathrm{N}$ availability (e.g. leaf $\mathrm{N}$ content) (Freschet, Violle, Bourget, Scherer-Lorenzen, \& Fort, 2018).

\section{Pathway to applications}

Weiner et al. (2009) described the reproductive-vegetative allometric relationship as a relatively fixedboundary condition, meaning that a plant cannot increase its reproductive output without growing more

first. Our findings highlight that, in a crop mixture, the interaction between the two intercropped species makes this boundary more complex given that the reproductive output of one component also depends on the performance of the other. From a practical viewpoint, the analysis of the intersection of allometric relationships enables the identification of plant biomass thresholds for each component of the mixture. We propose to use these thresholds as management criteria to cultivate each species up to its reproductive output maximum while accounting for the performance of the other.

We found that plant-plant interactions were a strong driver of yield variation in crop mixtures. In this case, an agronomic action on one species can readily influence the other even under relatively variable climate conditions, which is an important observation for designing and managing intercrops. For instance, if the goal of the farmer is to promote legume yield, using the cereal mainly to limit legume disease and lodging (e.g. 
size level of the target legume above which higher growth means higher yield, accounting for the interaction with the cereal. Conversely, if the goal is to promote both intercropped species, then trade-offs should be managed to be close to the threshold in order to avoid a strong dominance of one of the two species.

Moreover, results at the family rank are particularly interesting because intercrops are grown to meet a variety of objectives. While intercrop systems are often designed to achieve a balance in the yield of both species harvested (Hauggaard-Nielsen et al., 2008; Pelzer, Hombert, Jeuffroy, \& Makowski, 2014), they can also help to increase legume acreage, which is a major issue in the current agronomic context in order to decrease greenhouse gas emissions - through decreased use of synthetic $N$ fertilizer and increased production of plant protein for human consumption (Magrini et al., 2018; Zander et al., 2016).

\section{Authors' contributions}

NG, PC, CV, FF designed and planned the study;

LB, GCH, AC, HHN, PH, ESJ, EPJ, EJ, BK, CN, EP provided data;

NG, PC, CB, RM designed, formatted and homogenized the database;

NG, PC, XG, RM analyzed the data;

NG, PC, CV, FF, EP, SM, XG, RM, HHN, LB, AC, CN, NM participated in the writing and editing.

\section{Acknowledgements}

The authors thank all the technical staff who helped to acquire this vast dataset, and Michael and Michelle Corson for their helpful comments and English revision. This study was supported by the French National Research Agency under the Investments for the Future Program (ANR-16-CONV-0004) and by the INRA Environment and Agronomy Division through the project IDEA (Intra- and interspecific diversity mixture in agriculture). CV was supported by the European Research Council (ERC) Starting Grant Project 
Bedoussac, L., \& Justes, E. (2010a). Dynamic analysis of competition and complementarity for light and $\mathrm{N}$ use to understand the yield and the protein content of a durum wheat-winter pea intercrop. Plant and Soil, 330(1-2), 37-54. doi: $\underline{10.1007 / s 11104-010-0303-8}$

Bedoussac, L., \& Justes, E. (2010b). The efficiency of a durum wheat-winter pea intercrop to improve yield and wheat grain protein concentration depends on $\mathrm{N}$ availability during early growth. Plant and Soil, 330(1-2), 19-35. doi: $\underline{10.1007 / s 11104-009-0082-2}$

Beillouin, D., Ben-Ari, T., \& Makowski, D. (2019). A dataset of meta-analyses on crop diversification at the global scale.

Bonser, S. P. (2013). High reproductive efficiency as an adaptive strategy in competitive environments. Functional

Ecology, 27(4), 876-885. doi: 10.1111/1365-2435.12064

Cadotte, M. W. (2017). Functional traits explain ecosystem function through opposing mechanisms. Ecology Letters, 20(8), 989-996. doi: 10.1111/ele.12796

Cheplick, G. P. (2005). The Allometry of Reproductive Allocation. In E. G. Reekie \& F. A. Bazzaz (Eds.), Reproductive Allocation in Plants (pp. 97-128). Burlington: Academic Press. doi: 10.1016/B978-012088386-8/50004-1

Coomes, D. A., Lines, E. R., \& Allen, R. B. (2011). Moving on from Metabolic Scaling Theory: Hierarchical models of tree growth and asymmetric competition for light. Journal of Ecology, 99(3), 748-756. doi: 10.1111/j.13652745.2011.01811.x

Corre-Hellou, G., Brisson, N., Launay, M., Fustec, J., \& Crozat, Y. (2007). Effect of root depth penetration on soil nitrogen competitive interactions and dry matter production in pea-barley intercrops given different soil nitrogen supplies. Field Crops Research, 103(1), 76-85. doi: 10.1016/j.fcr.2007.04.008 
Deng, J., Ran, J., Wang, Z., Fan, Z., Wang, G., Ji, M., ... Brown, J. H. (2012). Models and tests of optimal density and maximal yield for crop plants. Proceedings of the National Academy of Sciences of the United States of America, 109(39), 15823-15828. doi: 10.1073/pnas.1210955109

Duchene, O., Vian, J.-F., \& Celette, F. (2017). Intercropping with legume for agroecological cropping systems: Complementarity and facilitation processes and the importance of soil microorganisms. A review. Agriculture, Ecosystems \& Environment, 240(Supplement C), 148-161. doi: 10.1016/j.agee.2017.02.019

Echarte, L., \& Andrade, F. H. (2003). Harvest index stability of Argentinean maize hybrids released between 1965 and 1993. Field Crops Research, 82(1), 1-12. doi: $10.1016 / 50378-4290(02) 00232-0$

Enquist, B. J., West, G. B., Charnov, E. L., \& Brown, J. H. (1999). Allometric scaling of production and life-history variation in vascular plants. Nature, 401(6756), 907-911. doi: 10.1038/44819

Filliben, J. J., \& McKinney, J. E. (1972). Confidence limits for the abscissa of intersection of two linear regressions. Journal of Research of the National Bureau of Standards -B. Mathematical Sciences, 3-4(76B), 179-192. Retrieved from http://archive.org/details/iresv76Bn3-4p179

Freschet, G. T., Violle, C., Bourget, M. Y., Scherer-Lorenzen, M., \& Fort, F. (2018). Allocation, morphology, physiology, architecture: The multiple facets of plant above- and below-ground responses to resource stress. New Phytologist, 219(4), 1338-1352. doi: 10.1111/nph.15225

407

Gaba, S., Alignier, A., Aviron, S., Barot, S., Blouin, M., Hedde, M., ... Couvet, D. (2018). Ecology for Sustainable and Multifunctional Agriculture. In S. Gaba, B. Smith, \& E. Lichtfouse (Eds.), Sustainable Agriculture Reviews 28: Ecology for Agriculture (Vol. 28, pp. 1-46). Development, 39(2), 20. doi: 10.1007/s13593-019-0562-6

413 Goldberg, D. E. (1990). Components of resource competition in plant communities. In J. B. Grace \& D. Tilman (Eds.), 414 Perspectives on plant competition (pp. 27-49). 
Hauggaard-Nielsen, H., Gooding, M., Ambus, P., Corre-Hellou, G., Crozat, Y., Dahlmann, C., ... Jensen, E. S. (2009a). Peabarley intercropping for efficient symbiotic $\mathrm{N}$-2-fixation, soil $\mathrm{N}$ acquisition and use of other nutrients in European organic cropping systems. Field Crops Research, 113(1), 64-71. doi: 10.1016/i.fcr.2009.04.009

Hauggaard-Nielsen, H., Gooding, M., Ambus, P., Corre-Hellou, G., Crozat, Y., Dahlmann, C., ... Jensen, E. S. (2009b). Peabarley intercropping and short-term subsequent crop effects across European organic cropping conditions. Nutrient

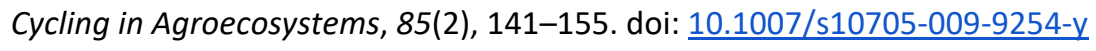

Hauggaard-Nielsen, H., Jørnsgaard, B., Kinane, J., \& Jensen, E. S. (2008). Grain legume-cereal intercropping: The practical application of diversity, competition and facilitation in arable and organic cropping systems. Renewable Agriculture and

Hay, R. (1995). Harvest Index - a Review of Its Use in Plant-Breeding and Crop Physiology. Annals of Applied Biology, 126(1), 197-216. doi: 10.1111/i.1744-7348.1995.tb05015.x

Hinsinger, P., Betencourt, E., Bernard, L., Brauman, A., Plassard, C., Shen, J., ... Zhang, F. (2011). P for Two, Sharing a Scarce Resource: Soil Phosphorus Acquisition in the Rhizosphere of Intercropped Species. Plant Physiology, 156(3), 1078-1086. doi: 10.1104/pp.111.175331 Sustainable Development, 40(1), 5. doi: 10.1007/s13593-020-0607-x and $\mathrm{N}$ use in pea-barley, faba bean-barley and lupin-barley intercrops grown at two temperate locations. Journal of Agricultural Science, 142, 617-627. doi: $\underline{10.1017 / 50021859604004745}$ traits have globally consistent effects on competition. Nature, 529(7585), 204-U174. doi: 10.1038/nature16476 
Li-li, M., Li-zhen, Z., Si-ping, Z., Evers, J. B., Werf, W. van der, Jing-jing, W., ... Spiertz, H. (2015). Resource use efficiency,

441 ecological intensification and sustainability of intercropping systems. Journal of Integrative Agriculture, 14(8), 1542442 1550. doi: $\underline{10.1016 / \text { S2095-3119(15)61039-5 }}$

443 Lin, B. B. (2011). Resilience in Agriculture through Crop Diversification: Adaptive Management for Environmental 444 Change. Bioscience, 61(3), 183-193. doi: 10.1525/bio.2011.61.3.4

445 Litrico, I., \& Violle, C. (2015). Diversity in Plant Breeding A New Conceptual Framework. Trends in Plant Science, 20(10), 604-613. doi: $\underline{10.1016 / j . t p l a n t s .2015 .07 .007}$

447 Liu, J., Wang, G.-X., Wei, L., \& Wang, C.-M. (2008). Reproductive allocation patterns in different density populations of spring wheat. Journal of Integrative Plant Biology, 50(2), 141-146. doi: 10.1111/i.1744-7909.2007.00602.x

449 Magrini, M.-B., Anton, M., Chardigny, J.-M., Duc, G., Duru, M., Jeuffroy, M.-H., ... Walrand, S. (2018). Pulses for 450 Sustainability: Breaking Agriculture and Food Sectors Out of Lock-In. Frontiers in Sustainable Food Systems, 2, UNSP 64. doi: $10.3389 /$ fsufs.2018.00064

Malézieux, E. (2012). Designing cropping systems from nature. Agronomy for Sustainable Development, 32(1), 15-29. doi: $\underline{10.1007 / s 13593-011-0027-z}$

Malézieux, E., Crozat, Y., Dupraz, C., Laurans, M., Makowski, D., Ozier-Lafontaine, H., ... Valantin-Morison, M. (2009). Mixing plant species in cropping systems: Concepts, tools and models. A review. Agronomy for Sustainable Development, 29(1), 43-62. doi: 10.1051/agro:2007057

Mariotti, M., Masoni, A., Ercoli, L., \& Arduini, I. (2009). Above- and below-ground competition between barley, wheat, 458 lupin and vetch in a cereal and legume intercropping system. Grass and Forage Science, 64(4), 401-412. doi: $\underline{10.1111 / j .1365-2494.2009 .00705 . x}$

460 Mayfield, M. M., \& Levine, J. M. (2010). Opposing effects of competitive exclusion on the phylogenetic structure of 461 communities. Ecology Letters, 13(9), 1085-1093. doi: 10.1111/i.1461-0248.2010.01509.x 
Naudin, C., Corre-Hellou, G., Pineau, S., Crozat, Y., \& Jeuffroy, M.-H. (2010). The effect of various dynamics of N availability on winter pea-wheat intercrops: Crop growth, $\mathrm{N}$ partitioning and symbiotic N-2 fixation. Field Crops Research, 119(1), 2-11. doi: 10.1016/i.fcr.2010.06.002

Naudin, C., Werf, H. M. G. van der, Jeuffroy, M.-H., \& Corre-Hellou, G. (2014). Life cycle assessment applied to peawheat intercrops: A new method for handling the impacts of co-products. Journal of Cleaner Production, 73, 80-87. doi:

Nee, S., Colegrave, N., West, S. A., \& Grafen, A. (2005). The illusion of invariant quantities in life histories. Science, 309(5738), 1236-1239. doi: 10.1126/science.1114488

Niklas, K. J., \& Enquist, B. J. (2001). Invariant scaling relationships for interspecific plant biomass production rates and body size. Proceedings of the National Academy of Sciences of the United States of America, 98(5), 2922-2927. doi: $10.1073 /$ pnas. 041590298

Pelzer, E., Bazot, M., Guichard, L., \& Jeuffroy, M.-H. (2016). Crop Management Affects the Performance of a Winter PeaWheat Intercrop. Agronomy Journal, 108(3), 1089-1100. doi: 10.2134/agronj2015.0440

Pelzer, E., Bazot, M., Makowski, D., Corre-Hellou, G., Naudin, C., Al Rifaï, M., ... Jeuffroy, M.-H. (2012). Pea-wheat intercrops in low-input conditions combine high economic performances and low environmental impacts. European Journal of Agronomy, 40(Supplement C), 39-53. doi: 10.1016/i.eja.2012.01.010

Pelzer, E., Hombert, N., Jeuffroy, M.-H., \& Makowski, D. (2014). Meta-Analysis of the Effect of Nitrogen Fertilization on Annual Cereal-Legume Intercrop Production. Agronomy Journal, 106(5), 1775-1786. doi: 10.2134/agronj13.0590

Poorter, H., Jagodzinski, A. M., Ruiz-Peinado, R., Kuyah, S., Luo, Y., Oleksyn, J., ... Sack, L. (2015). How does biomass distribution change with size and differ among species? An analysis for 1200 plant species from five continents. New Phytologist, 208(3), 736-749. doi: 10.1111/nph.13571

Poorter, H., \& Nagel, O. (2000). The role of biomass allocation in the growth response of plants to different levels of light, CO2, nutrients and water: A quantitative review. Australian Journal of Plant Physiology, 27(6), 595-607. doi: $\underline{10.1071 / P P 99173}$

Poorter, H., \& Sack, L. (2012). Pitfalls and possibilities in the analysis of biomass allocation patterns in plants. Frontiers 
Qin, X.-I., Weiner, J., Qi, L., Xiong, Y.-C., \& Li, F.-m. (2013). Allometric analysis of the effects of density on reproductive 491 allocation and Harvest Index in 6 varieties of wheat (Triticum). Field Crops Research, 144, 162-166. doi:

R Core Team. (2019). R: A Language and Environment for Statistical Computing. Vienna, Austria: R Foundation for Statistical Computing. Retrieved from https://www.R-project.org/

Satorre, E. H., \& Snaydon, R. W. (1992). A comparison of root and shoot competition between spring cereals and Avena fatua L. Weed Research, 32(1), 45-55. doi: 10.1111/i.1365-3180.1992.tb01861.x

Stoll, P., \& Weiner, J. (2000). A neighborhood view of interactions among individual plants. In U. Dieckmann, R. Law, \&

J. A. J. Metz (Eds.), The geometry of ecological interactions: Simplifying spatial complexity (pp. 11-27). Cambridge University Press.

Sugiyama, S., \& Bazzaz, F. A. (1998). Size dependence of reproductive allocation: The influence of resource availability, competition and genetic identity. Functional Ecology, 12(2), 280-288. doi: 10.1046/j.1365-2435.1998.00187.x

Tang, X., Placella, S. A., Dayde, F., Bernard, L., Robin, A., Journet, E.-P., ... Hinsinger, P. (2016). Phosphorus availability and microbial community in the rhizosphere of intercropped cereal and legume along a P-fertilizer gradient. Plant and Soil, 407(1-2), 119-134. doi: 10.1007/s11104-016-2949-3

505 Taskinen, S., \& Warton, D. I. (2013). Robust tests for one or more allometric lines. Journal of Theoretical Biology, 333, 38-46. doi: 10.1016/i.jtbi.2013.05.010

Thorsted, M. D., Weiner, J., \& Olesen, J. E. (2006). Above- and below-ground competition between intercropped winter 508 wheat Triticum aestivum and white clover Trifolium repens. Journal of Applied Ecology, 43(2), 237-245. doi: $\underline{10.1111 / j .1365-2664.2006 .01131 . x}$

510 Unkovich, M., Baldock, J., \& Forbes, M. (2010). Advances in Agronomy (D. L. Sparks, Ed.). doi: 10.1016/S0065-

\section{$511 \quad \underline{2113(10) 05005-4}$}

512 Vasseur, F., Exposito-Alonso, M., Ayala-Garay, O. J., Wang, G., Enquist, B. J., Vile, D., ... Weigel, D. (2018). Adaptive 513 diversification of growth allometry in the plant Arabidopsis thaliana. Proceedings of the National Academy of Sciences, 514 115(13), 3416-3421. doi: 10.1073/pnas.1709141115 
Vasseur, F., Violle, C., Enquist, B. J., Granier, C., \& Vile, D. (2012). A common genetic basis to the origin of the leaf economics spectrum and metabolic scaling allometry. Ecology Letters, 15(10), 1149-1157. doi: 10.1111/i.1461-

518 Vega, C. R. C., Sadras, V. O., Andrade, F. H., \& Uhart, S. A. (2000). Reproductive allometry in soybean, maize and sunflower. Annals of Botany, 85(4), 461-468. doi: 10.1006/anbo.1999.1084

Viguier, L., Bedoussac, L., Journet, E.-P., \& Justes, E. (2018). Yield gap analysis extended to marketable grain reveals the profitability of organic lentil-spring wheat intercrops. Agronomy for Sustainable Development, 38(4), 39. doi: $\underline{10.1007 / s 13593-018-0515-5}$ about allometric lines. Methods in Ecology and Evolution, 3(2), 257-259. doi: 10.1111/j.2041-210X.2011.00153.x

Warton, D. I., Wright, I. J., Falster, D. S., \& Westoby, M. (2006). Bivariate line-fitting methods for allometry. Biological Reviews, 81(2), 259-291. doi: 10.1017/S1464793106007007

Weiner, J. (2004). Allocation, plasticity and allometry in plants. Perspectives in Plant Ecology Evolution and Systematics, 6(4), 207-215. doi: $10.1078 / 1433-8319-00083$

Weiner, J., Campbell, L. G., Pino, J., \& Echarte, L. (2009). The allometry of reproduction within plant populations. Journal of Ecology, 97(6), 1220-1233. doi: 10.1111/j.1365-2745.2009.01559.x

531 West, G. B., Brown, J. H., \& Enquist, B. J. (1997). A general model for the origin of allometric scaling laws in biology. Science, 276(5309), 122-126. doi: 10.1126/science.276.5309.122

533 West, G. B., Brown, J. H., \& Enquist, B. J. (1999). A general model for the structure and allometry of plant vascular 534 systems. Nature, 400(6745), 664-667.

535 Wickham, H. (2016). Ggplot2: Elegant Graphics for Data Analysis (2nd ed.). Springer International Publishing. Retrieved 536 from https://www.springer.com/gp/book/9783319242750 
539 Willey, R. W. (1979). Intercropping: Its importance and research needs. Part 1, competition and yield advantages. Place

540 of publication not identified: Commonwealth Agricultural Bureaux.

541 Xie, Y. (2015). Dynamic Documents with R and knitr, Second Edition (2nd ed.). Boca Raton: Routledge.

542 Yu, Y., Stomph, T.-J., Makowski, D., Zhang, L., \& Werf, W. van der. (2016). A meta-analysis of relative crop yields in 543 cereal/legume mixtures suggests options for management. Field Crops Research, 198, 269-279. doi:

\section{$544 \quad$ 10.1016/i.fcr.2016.08.001}

545 Zander, P., Amjath-Babu, T. S., Preissel, S., Reckling, M., Bues, A., Schlaefke, N., ... Watson, C. (2016). Grain legume 546 decline and potential recovery in European agriculture: A review. Agronomy for Sustainable Development, $36(2), 26$.

547 doi: $10.1007 /$ s13593-016-0365-y 